\title{
PENGARUH PEMBERIAN SARAPAN TINGGI PROTEIN TERHADAP TINGKAT RASA KENYANG WANITA OBESITAS
}

\author{
Fidela Zahradika Fathimah, Tatik Mulyati*) \\ Program Studi Ilmu Gizi Fakultas Kedokteran Universitas Diponegoro \\ J1.Dr.Sutomo No.18, Semarang, Telp (024) 8453708, Email : gizifk@ undip.ac.id
}

\begin{abstract}
Background: Obesity has emerged as an epidemic global problem and has been well established as an important risk factor for many degenerative diseases. Many strategies have been conducted to reduce energy intake in weight loss program, which one of those was hunger dan fullness control. High protein breakfast can increase satiety levels because proteins have the most physiological and metabolism satiating effect.

Methods:Experimental study with control group pre-post test design was conducted. Subjects were 22 obesity women with BMI between $25 \mathrm{~kg} / \mathrm{m}^{2}-32 \mathrm{~kg} / \mathrm{m}^{2}$. Subjects were divided into two groups (treatment group and control group) using simple random sampling method. During 5 days of intervention, the treatment group gets $362.5 \mathrm{kcal}$ breakfasts which contain 25\% protein, while the control group gets 14\% protein. Satiety level was measured every 3 hours each day after breakfast using $100 \mathrm{~mm}$ Satiety Labeled Intensity Magnitude (SLIM) Bipolar Scale. ShapiroWilk was used to assess normality, while paired t-test and Mann-Whitney test were used as statistical analyzes.

Result: Breakfast with 25\% protein content increased satiety level and there was significant difference between high protein breakfastcompared to normal protein at 120, 150, and 180 minutes after meal $(p=0.002, p=0.001, p=$ 0.000).

Conclusions: Consumption of high protein breakfast lead to increase in satiety level in order to control the hungry feeling.
\end{abstract}

\section{ABSTRAK}

Latar Belakang: Masalah diet dan berat badan menjadi masalah epidemi global saat ini, di mana sebagian besar penduduk dunia mengalami kelebihan berat badan dan obesitas. Obesitas jika tidak segera ditangani dapat menjadi faktor risiko utama terjadinya penyakit degeneratif. Beberapa cara dilakukan untuk mengurangi asupan energy dalam diet penurunan berat badan, salah satunya dengan pengaturan rasa lapar dan kenyang. Sarapan tinggi protein dapat mempengaruhi rasa kenyang karena protein memiliki efek fisiologis dan metabolisme yang paling mengenyangkan.

Metode : Jenis penelitian ini adalah true experimental dengan rancangan control group pre-post test. Subjek sebanyak 22 orang wanita obesitas dengan IMT $25 \mathrm{~kg} / \mathrm{m}^{2}-32 \mathrm{~kg} / \mathrm{m}^{2}$. Subyek dibagi menjadi kelompok kontrol dan perlakuan. Kelompok perlakuan mendapat sarapan dengan $25 \%$ protein, sedangkan kelompok control mendapat sarapan 14\% protein dan dilakukan selama 5 hari. Tingkat rasa kenyang diukur setiap hari selama 3 jam setelah makan dengan 100mm Satiety Labeled Intensity Magnitude (SLIM) bipolarscale. Uji normalitas menggunakan Shapiro-Wilk dan analisis statisitik menggunakan uji independent t-test dan Mann-Whitney.

Hasil :Pemberian sarapan dengan protein 25\% dapat meningkatkan rasa kenyang setelah makan dan ada perbedaan yang bermakna di 120 menit, 150 menit, dan 180 menit setelah makan $(p=0.002, p=0,001, p=0,000)$ dibandingkan dengan pemberian protein $14 \%$.

Kesimpulan : Sarapan dengan $25 \%$ protein dapat meningkatkan rasa kenyang setelah makan dan membantu pengendalian rasa lapar.

Kata Kunci : sarapan tinggi protein; rasa kenyang; obesitas

\section{PENDAHULUAN}

Masalah diet dan berat badan menjadi masalah epidemi global saat ini, di mana sebagian besar penduduk dunia mengalami kelebihan berat badan dan obesitas. Obesitas menurut World Health Organization (WHO) adalah suatu kondisi di mana terjadi kelebihan lemak di tubuh yang dapat berbahaya bagi kesehatan. ${ }^{1}$ Data WHO tahun 2008 menunjukkan bahwa lebih dari 1,4 milyar orang dewasa di dunia mengalami kelebihan berat badan. Data Riskesdas tahun 2013 menunjukkan bahwa prevalensi berat badan lebih di Indonesia sebesar 13,5\% dan obesitas 15,4\%. Angka ini meningkat dari tahun 2010, yaitu $10 \%$ untuk gizi lebih dan $11,7 \%$ untuk obesitas, dengan persentase wanita overweight dan obesitas sebesar 32,9\%, lebih tinggi dibandingkan dengan laki-laki yaitu 19,7\%. Jawa Tengah merupakan propinsi dengan prevalensi obesitas di bawah rata-rata nasional yaitu $12,8 \%$, namun angkanya terus meningkat secara signifikan dari tahun ke tahun sehingga jika tidak segera ditanggulangi dapat meningkat tidak terkendali. ${ }^{2,3}$

\footnotetext{
*)Penulis Penanggungjawab
} 
Obesitas jika tidak segera ditangani dapat menjadi faktor risiko utama terjadinya penyakitpenyakit kronik metabolik, seperti hipertensi, penyakit kardiovaskuler, diabetes tipe 2, dan kanker. ${ }^{4,5}$ Oleh karena itu, beberapa cara dilakukan untuk menurunkan berat badan, salah satunya dengan mengasup kalori lebih sedikit dari kebutuhan. Mengurangi asupan energi yang masuk sulit dilakukan karena cenderung menimbulkan rasa lapar disebabkan karena jumlah makanan yang dikonsumsiberkurang dari biasanya. Salah satu cara untuk mengurangi asupan energi adalah dengan mengatur komposisi makronutrien dalam makanan yang dapat mempengaruhi rasa lapar dan kenyang dengan memberikan makanan tinggi protein yang dikombinasikan dengan rasio karbohidrat yang lebih rendah. ${ }^{6}$

Protein disebut sebagai makronutrien yang paling mengenyangkan karena protein memiliki efek thermal yang lebih besar dibanding karbohidrat dan lemak sebab protein harus langsung dimetabolisme dan tidak dapat disimpan dalam tubuh. ${ }^{7}$ Faktor lain yaitu dari efek fisiologis seperti faktor metabolisme, hormon-hormon pencernaan, dan fungsi gastrointestinal.Pencernaan protein memiliki pengaruh yang berbeda terhadap hormon kolesistokinin, GLP-1, dan ghrelin dibandingkan karbohidrat dan lemak. ${ }^{8-10}$

Waktu pemberian makan berprotein tinggi memberikan pengaruh yang berbeda pada pengaturan berat badan. ${ }^{11,12}$ Sarapan yang disebut sebagai waktu makan paling penting menjadi pilihan paling tepat dalam memberikan diet tinggi protein, sebab apa yang dimakan ketika sarapan memiliki pengaruh besar terhadap asupan total harian. ${ }^{11-14}$ Melewatkan waktu sarapan dapat memicu makan lebih banyak sepanjang hari, karena cenderung akan mengkonsumsi makanan camilan yang tinggi karbohidrat dan rendah nilai gizinya terutama di sore atau malam hari. Sarapan yang sehat dapat membentuk pola makan sehat dimana kadar glukosa darah dapat lebih terkontrol. ${ }^{12-14}$

Penelitian terhadap 9 laki-laki obesitas $\left(\mathrm{IMT} \pm 32,7 \mathrm{~kg} / \mathrm{m}^{2}\right)$ di Kansas, Amerika tentang pengaruh makanan tinggi protein terhadap rasa kenyang responden yang diberikan pada waktu sarapan, makan siang, dan makan malam. Masingmasing subjek diberikan 5 jenis pemberian makanan, yaitu makanan dengan protein normal (0,8 g/hari), makanan tinggi protein $(1,4 \mathrm{~g} / \mathrm{hari}$ atau $28 \mathrm{~g}$ setiap makan) ketika sarapan, makan siang, makan malam, dan di seluruh waktu makan masing-masing selama 6 hari. Protein yang diberikan $25 \%$ terdiri dari protein hewani seperti telur dan daging babi. Hasil penelitian menyebutkan bahwa makanan tinggi protein yang diberikan ketika sarapan lebih berpengaruh dalam meningkatkan rasa kenyang dibandingkan waktu makan lainnya. ${ }^{11}$

Berdasarkan uraian tersebut maka peneliti melakukan penelitian lebih lanjut mengenai pengaruh sarapan tinggi protein terhadap rasa kenyang pada wanita obesitas.

\section{METODE PENELITIAN}

Penelitian ini merupakan penelitian true experimental dengan rancangan pre-post group design. $^{20}$ Variabel bebas dalam penelitian ini adalah pemberian sarapan dengan protein normal yaitu $14 \%$ dan protein tinggi yaitu $25 \%$.Variabel terikatnya adalah rasa kenyang wanita obesitas. Pelaksanaan penelitian telah mendapat persetujuan dari Komite Etik Fakultas Kedokteran Universitas Diponegoro melalui terbitnya Ethical Clearance.

Subjek penelitian ini adalah pegawai wanita Badan Pengkajian Teknologi Pertanian Jawa Tengah dan guru wanita SD Srondol Wetan, Semarang. Kriteria inklusi penelitian ini adalah wanita yang memiliki indeks massa tubuh (IMT) $25-32 \mathrm{~kg} / \mathrm{m}^{2}$, berusia $30-60$ tahun, dalam keadaan sehat dan tidak menderita penyakit infeksi maupun metabolisme terkait gizi, tidak mengalami penyakit ginjal atau yang perlu pembatasan protein, tidak mengalami penurunan $\mathrm{BB}$ atau sedang mengikuti diet selama 6 bulan terakhir, tidak menjalani terapi obat yang dapat mempengaruhi nafsu makan, tidak merokok, dan bersedia menjadi subjek penelitian dengan mengisi informed consent.

Penentuan subjek dilakukan dengan metode consecutive sampling. Sebanyak 56 orang bersedia ditimbang dan diwawancarai untuk proses skrining awal dan diperoleh sebanyak 22 orang yang memenuhi kriteria inklusi penelitian. Subjek dibagi menjadi 2 kelompok dengan metode simple random sampling sehingga diperoleh 11 sampel pada kelompok perlakuan dan 11 sampel pada kelompok kontrol.

Pemberian sarapan dalam bentuk makanan biasa padat berupa nasi, lauk, dan sayur. Kebutuhan energi harian dihitung dengan rumus BMR Harris-Benedict dikalikan faKtor aktifitas kemudian dikurangi 500 kkal. ${ }^{15}$ Energi untuk sarapan sebanyak 25\% dari kebutuhan energi harian. Kelompok perlakuan mendapat 25\% protein (25 gram), sedangkan kelompok kontrol $14 \%$ protein (13 gram). Makanan sumber protein yang digunakan berasal dari lauk hewani rendah lemak yaitu ayam, ikan, dan daging sapi tanpa lemak, dengan perbandingan antara kelompok 
perlakuan dan kontrol adalah 1 penukar dan 3 penukar lauk hewani. Nasi diberikan sebanyak 100 gram untuk kelompok perlakuan dan 150 gram untuk kelompok kontrol. Sayur yang digunakan adalah sayur rendah serat seperti mentimun, jamur, kembang kol, dan brokoli dan diberikan sebanyak 50 gram untuk seluruh kelompok.

Sebelum diberikan intervensi, kelompok tinggi protein diperiksa kadar ureum dan kreatinin untuk memastikan kadarnya masih dalam batas normal. Sarapan didistribusikan kepada subjek selama 5 hari pukul 06.00 - 07.00. Rasa kenyangdiukur setiap hari dengan rentang 30 menit sebelum makan serta 30 menit, 60 menit, 90 menit, 120 menit, dan 180 menit setelah makan. Selama intervensi subjek diharuskan untuk menghabiskan makanan yang disediakan peneliti dan dilarang makan dan minum apapun kecuali air putih dari bangun tidur hingga 3 jam setelah sarapan.

Pengukuran rasa kenyang menggunakan kuesioner skala bipolar $100 \mathrm{~mm}$ Satiety Labeled Intensity Magnitude (SLIM) yang diisi sendiri oleh subjek dengan pelatihan sebelumnya.Subjek diminta memberi tanda pada garis yang menunjukkan skor rasa kenyangsubjek. Tingkatan rasa lapar dan kenyang ditandai di titik dengan nilai tertentu, yaitu nilai 0 untuk titik tengah yang berarti tidak lapar/kenyang, -18,6 untuk agak lapar, -38,2 untuk lumayan lapar, -56,2 untuk sangat lapar, -67,4 untuk sangat sangat lapar, dan 100 untuk batas tingkat kelaparan, sedangkan untuk rasa kenyang yaitu nilai 31,9 untuk agak kenyang, 46,7 untuk lumayan kenyang, 74,3 untuk sangat kenyang, 79,4 untuk sangat sangat kenyang, dan 100 untuk batas tingkat kekenyangan. ${ }^{16}$

Peneliti memberi arahan dan mengawasi proses pengisian kuesioner. Pengukuran ini dilakukan 5 kali dan diambil rata-ratanya. Pada hari kelima dilakukan penimbangan berat badan post-intervensi.

Uji normalitas menggunakan uji Shapiro Wilk. Karakteristik subjek dianalisis dengan menggunakan analisis deskriptif. Perbedaan pengaruh perlakuan kedua kelompok terhadap rasa kenyang dianalisis menggunakan uji independent t-testuntuk data berdistribusi normal dan uji Mannwhitneyuntuk data berdistribusi tidak normal.

\section{HASIL PENELITIAN \\ Gambaran UmumSubjek}

Gambaran umum subjek yang terdiri dari usia, pendidikan, dan aktifitas fisik disajikan dalam tabel 1 .

Tabel 1. Gambaran Umum Subjek

\begin{tabular}{|c|c|c|c|c|c|}
\hline \multirow{2}{*}{$\begin{array}{l}\text { Gambaran Umum } \\
\text { Subjek }\end{array}$} & \multicolumn{2}{|c|}{ Perlakuan $(n=11)$} & \multicolumn{2}{|c|}{ Kontrol (n=11) } & \multirow[t]{2}{*}{$\boldsymbol{P}$} \\
\hline & $\mathbf{n}$ & $\%$ & $\mathbf{N}$ & $\%$ & \\
\hline \multicolumn{6}{|l|}{ Umur } \\
\hline 30-39 tahun & 3 & 13,6 & 2 & 9 & \multirow{3}{*}{$0,609^{\mathrm{a}}$} \\
\hline 40-49 tahun & 4 & 18,2 & 6 & 27,3 & \\
\hline 50-59 tahun & 4 & 18,2 & 3 & 13,6 & \\
\hline \multicolumn{6}{|l|}{ Pendidikan } \\
\hline SMA & 3 & 13,6 & 3 & 13,6 & \multirow{3}{*}{$0,765^{\mathrm{b}}$} \\
\hline S1 & 7 & 31,9 & 6 & 27,3 & \\
\hline $\mathbf{S 2}$ & 1 & 4,5 & 2 & 9 & \\
\hline \multicolumn{6}{|l|}{ Aktifitas Fisik } \\
\hline Low Active & 9 & 45,5 & 7 & 36,3 & \multirow{2}{*}{$0,054^{\mathrm{b}}$} \\
\hline Aktif & 2 & 4,5 & 4 & 13,6 & \\
\hline
\end{tabular}

a. Uji beda independent t-test

b. Uji Mann Whitney

Subjek pada kedua kelompok sebagian besar berumur $40-49$ tahun $(45,4 \%)$, dan memiliki pendidikan S1 $(59,1 \%)$. Sedangkan aktifitas fisik terbanyak berada pada levellow activeatau aktifitas ringan $(81,8 \%)$. Hasil uji beda terhadap usia, pendidikan, dan aktifitas fisik kelompok perlakuan maupun kontrol menunjukkan tidak ada perbedaan antara kedua kelompok ( $>0,05$ ).

\section{Asupan Sarapan Sebelum Intervensi}

Uji beda asupan sarapan antar kelompok dilakukan untuk mengetahui homogenitas subjek sebelum intervensi. 
Tabel 2. Asupan sarapan sebelum intervensi

\begin{tabular}{lccc}
\hline & $\begin{array}{c}\text { Perlakuan }(\mathbf{n}=11) \\
(\text { Mean } \pm \text { SD) }\end{array}$ & $\begin{array}{c}\text { Kontrol }(\mathbf{n}=11) \\
(\text { Mean } \pm \text { SD) }\end{array}$ & P \\
\hline Energi (kkal) & $567,45 \pm 134,86$ & $523,02 \pm 139,99$ & $0,457^{\mathrm{a}}$ \\
Protein (g) & $17,55 \pm 5,42$ & $17,16 \pm 6,90$ & $0,881^{\mathrm{a}}$ \\
Lemak (g) & $19,60 \pm 6,12$ & $21,94 \pm 6,24$ & $0,514^{\mathrm{a}}$ \\
Karbohidrat (mg) & $80,89 \pm 23,56$ & $65,63 \pm 17,63$ & $0,101^{\mathrm{a}}$ \\
Persentase protein (\%) & $12,27 \pm 2,20$ & $13,18 \pm 4,10$ & $0,524^{\mathrm{a}}$ \\
Persentase lemak (\%) & $30,45 \pm 7,98$ & $35,36 \pm 10,91$ & $0,242^{\mathrm{a}}$ \\
Persentase karbohidrat $(\%)$ & $56,91 \pm 7,85$ & $51,27 \pm 11,14$ & $0,185^{\mathrm{a}}$ \\
\hline
\end{tabular}

a. Uji beda independent $t$-test

Berdasarkan hasil pada tabel 2, persentase asupan protein kedua kelompok $<15 \%$.Tidak ada perbedaan asupan energi, protein, lemak, dan karbohidrat antara kelompok perlakuan dan kontrol $(\mathrm{p}>0,05)$.

\section{Rasa kenyang Sebelum Sarapan}

Tingkat rasa lapar dan kenyang subjek sebelum sarapan diukur 30 menit sebelum sarapan dan dilakukan uji beda untuk mengetahui homogenitas subjek sebelum intervensi.

Tabel 3. Rasa kenyang Sebelum Sarapan

\begin{tabular}{|c|c|c|c|c|c|}
\hline \multirow[t]{2}{*}{ Rasa kenyang } & \multicolumn{2}{|c|}{ Perlakuan $(\mathrm{n}=11)$} & \multicolumn{2}{|c|}{ Kontrol $(\mathrm{n}=11)$} & \multirow[t]{2}{*}{$P$} \\
\hline & $\mathbf{n}$ & $\%$ & $\mathbf{n}$ & $\%$ & \\
\hline Agak Lapar $(0-(-18,2))$ & 4 & 18,2 & 4 & 18,2 & \\
\hline Lumayan Lapar $(-18,2)-(-38,2)$ & 5 & 22,7 & 4 & 18,2 & $0,977^{\mathrm{a}}$ \\
\hline Sangat Lapar $(-38,2)-(-56,2)$ & 2 & 9,1 & 3 & 13,6 & \\
\hline
\end{tabular}

a. Uji independent $t$-test

Tabel 3 menunjukkan bahwa rasa kenyang di 30 menit sebelum sarapan pada kelompok kontrol dan perlakuan berada pada nilai minus. Sebagian besar subjek berada pada tingkat agak lapar dan lumayan lapar. Berdasarkan hasil uji beda, tidak ada perbedaan rasa kenyang pada kedua kelompok.

\section{Rasa kenyangSetelah Sarapan}

Rasa kenyang subjek setelah sarapan diukur dengan SLIM scale setiap 30 menit, 60 menit, 90 menit, 120 menit, 150 menit, dan 180 menit setelah sarapan. Data hasil pengukuran disajikan dalam tabel 4.

Tabel 4. Rasa kenyang Setelah Sarapan

\begin{tabular}{|c|c|c|c|c|c|}
\hline \multirow{2}{*}{\multicolumn{2}{|c|}{ Karakteristik Rasa kenyang }} & \multicolumn{2}{|c|}{$\begin{array}{c}\text { Perlakuan } \\
(n=11)\end{array}$} & \multicolumn{2}{|c|}{ Kontrol $(n=11)$} \\
\hline & & $\mathbf{n}$ & $\%$ & $\mathbf{n}$ & $\%$ \\
\hline \multicolumn{6}{|l|}{30 Menit } \\
\hline Lumayan Lapar & $(-18,2)-(-38,2)$ & - & - & - & - \\
\hline Agak Lapar & $(0-(-18,2))$ & - & - & - & - \\
\hline Agak Kenyang & $(0-31,9)$ & - & - & 1 & 9,1 \\
\hline Lumayan Kenyang & $(31,9-46,7)$ & 4 & 36,4 & 1 & 9,1 \\
\hline Sangat Kenyang & $(46,7-74,3)$ & 6 & 54,5 & 8 & 72,7 \\
\hline Sangat Sangat Keny & g $(74,3-79,4)$ & 1 & 9,1 & 1 & 9,1 \\
\hline \multicolumn{6}{|l|}{60 Menit } \\
\hline Lumayan Lapar & $(-18,2)-(-38,2)$ & - & - & - & - \\
\hline Agak Lapar & $(0-(-18,2))$ & - & - & 1 & 9,1 \\
\hline Agak Kenyang & $(0-31,9)$ & - & - & 2 & 18,2 \\
\hline Lumayan Kenyang & $(31,9-46,7)$ & 4 & 36,4 & 3 & 27,3 \\
\hline Sangat Kenyang & $(46,7-74,3)$ & 7 & 63,6 & 5 & 45,4 \\
\hline Sangat Sangat Keny & g $(74,3-79,4)$ & - & - & - & - \\
\hline \multicolumn{6}{|l|}{90 Menit } \\
\hline Lumayan Lapar & $(-18,2)-(-38,2)$ & - & - & - & - \\
\hline Agak Lapar & $(0-(-18,2))$ & - & - & 2 & 18,2 \\
\hline
\end{tabular}




\begin{tabular}{|c|c|c|c|c|c|}
\hline Agak Kenyang & $(0-31,9)$ & 1 & 9,1 & 1 & 9,1 \\
\hline Lumayan Kenyang & $(31,9-46,7)$ & 7 & 63,62 & 8 & 72,7 \\
\hline Sangat Kenyang & $(46,7-74,3)$ & 3 & 27,3 & - & - \\
\hline \multicolumn{2}{|c|}{ Sangat Sangat Kenyang $(74,3-79,4)$} & - & - & - & - \\
\hline \multicolumn{6}{|l|}{120 Menit } \\
\hline Lumayan Lapar & $(-18,2)-(-38,2)$ & - & - & - & - \\
\hline Agak Lapar & $(0-(-18,2))$ & - & - & 5 & 45,4 \\
\hline Agak Kenyang & $(0-31,9)$ & 5 & 45,4 & 5 & 45,4 \\
\hline Lumayan Kenyang & $(31,9-46,7)$ & 3 & 27,3 & 1 & 9,1 \\
\hline Sangat Kenyang & $(46,7-74,3)$ & 3 & 27,3 & - & - \\
\hline \multicolumn{2}{|c|}{ Sangat Sangat Kenyang $(74,3-79,4)$} & - & - & - & - \\
\hline \multicolumn{6}{|l|}{150 Menit } \\
\hline Lumayan Lapar & $(-18,2)-(-38,2)$ & - & - & 2 & 18,2 \\
\hline Agak Lapar & $(0-(-18,2))$ & - & - & 8 & 72,7 \\
\hline Agak Kenyang & $(0-31,9)$ & 7 & 63,6 & 1 & 9,1 \\
\hline Lumayan Kenyang & $(31,9-46,7)$ & 1 & 9,1 & - & - \\
\hline Sangat Kenyang & $(46,7-74,3)$ & 3 & 27,3 & - & - \\
\hline \multicolumn{2}{|c|}{ Sangat Sangat Kenyang $(74,3-79,4)$} & - & - & - & - \\
\hline \multicolumn{6}{|l|}{180 Menit } \\
\hline Lumayan Lapar & $(-18,2)-(-38,2)$ & 1 & 9,1 & 10 & 90,9 \\
\hline Agak Lapar & $(0-(-18,2))$ & 2 & 18,2 & 1 & 9,1 \\
\hline Agak Kenyang & $(0-31,9)$ & 3 & 27,3 & - & - \\
\hline Lumayan Kenyang & $(31,9-46,7)$ & 3 & 27,3 & - & - \\
\hline Sangat Kenyang & $(46,7-74,3)$ & 1 & 9,1 & - & - \\
\hline \multicolumn{2}{|c|}{ Sangat Sangat Kenyang $(74,3-79,4)$} & - & - & - & - \\
\hline
\end{tabular}

Tabel 4 menunjukkanrasa kenyang subjek setelah sarapan dengan interval 30 menit. Rasa kenyang kedua kelompok di 30 menit dan 60 menit sebagian besar berada pada tingkat sangat kenyang (63,6\% dan 50\%). Setelah 90 menit, rasa kenyang kedua kelompok menurun menjadi lumayan kenyang $(68,2 \%)$. Setelah 120 menit, rasa kenyang kelompok perlakuan berada pada tingkat agak kenyang $(45,4 \%)$, sedangkan kelompok kontrol berada di agak lapar $(45,4 \%)$. Agak lapar terjadi di kelompok kontrol pada menit ke-150 $(72,7 \%)$, sedangkan rata-rata kelompok perlakuan masih berada di tingkat agak kenyang $(63,6 \%)$. Setelah 180 menit, subjek di kelompok kontrol memiliki nilai minus di tingkat lumayan lapar (90,9\%), sedangkan sebagian besar subjek di kelompok perlakuan masih berada di tingkat lumayan kenyang $(27,3 \%)$.

Pengaruh Pemberian Sarapan Tinggi Protein terhadap Rasa kenyang Kelompok Perlakuan dan Kontrol

Pengaruh pemberian sarapan tinggi protein terhadap rasa kenyang disajikan dalam tabel berikut.

Tabel 5. Pengaruh Pemberian Sarapan Tinggi Protein terhadap Rasa kenyang

\begin{tabular}{lcccc}
\hline & \multirow{2}{*}{ Variabel } & Perlakuan $(\mathbf{n}=11)$ & Kontrol $(\mathbf{n}=11)$ & \multirow{2}{*}{$\boldsymbol{p}$} \\
\cline { 3 - 4 } Tingkat & Mean \pm SD & Mean \pm SD & \\
satiety & 60 menit sesudah & $57.85 \pm 15.35$ & $54.85 \pm 16.38$ & $0.662^{\mathrm{a}}$ \\
& 90 menit sesudah & $50.37 \pm 12.64$ & $39.98 \pm 22.49$ & $0.197^{\mathrm{a}}$ \\
& 120 menit sesudah & $43.13 \pm 12.15$ & $27.74 \pm 20.28$ & $0.178^{\mathrm{b}}$ \\
& 150 menit sesudah & $37.09 \pm 13.53$ & $7.62 \pm 17.81$ & $0.003^{\mathrm{b}}$ \\
& 180 menit sesudah & $11.05 \pm 27.58$ & $-11.82 \pm 9.78$ & $0.000^{\mathrm{a}}$ \\
\hline
\end{tabular}

\footnotetext{
a. Uji independent t-test

b.Uji Mann Whitney
}

Hasil uji beda pada tabel 4 menunjukkan bahwa tidak ada perbedaan rasa kenyang antara kelompok perlakuan dan kontrol di 30 menit, 60 menit, dan 90 menit setelah makan. Ada perbedaan rasa kenyang di 120 menit, 150 menit, dan 180 menit setelah makan antara kelompok perlakuan dan kontrol. 


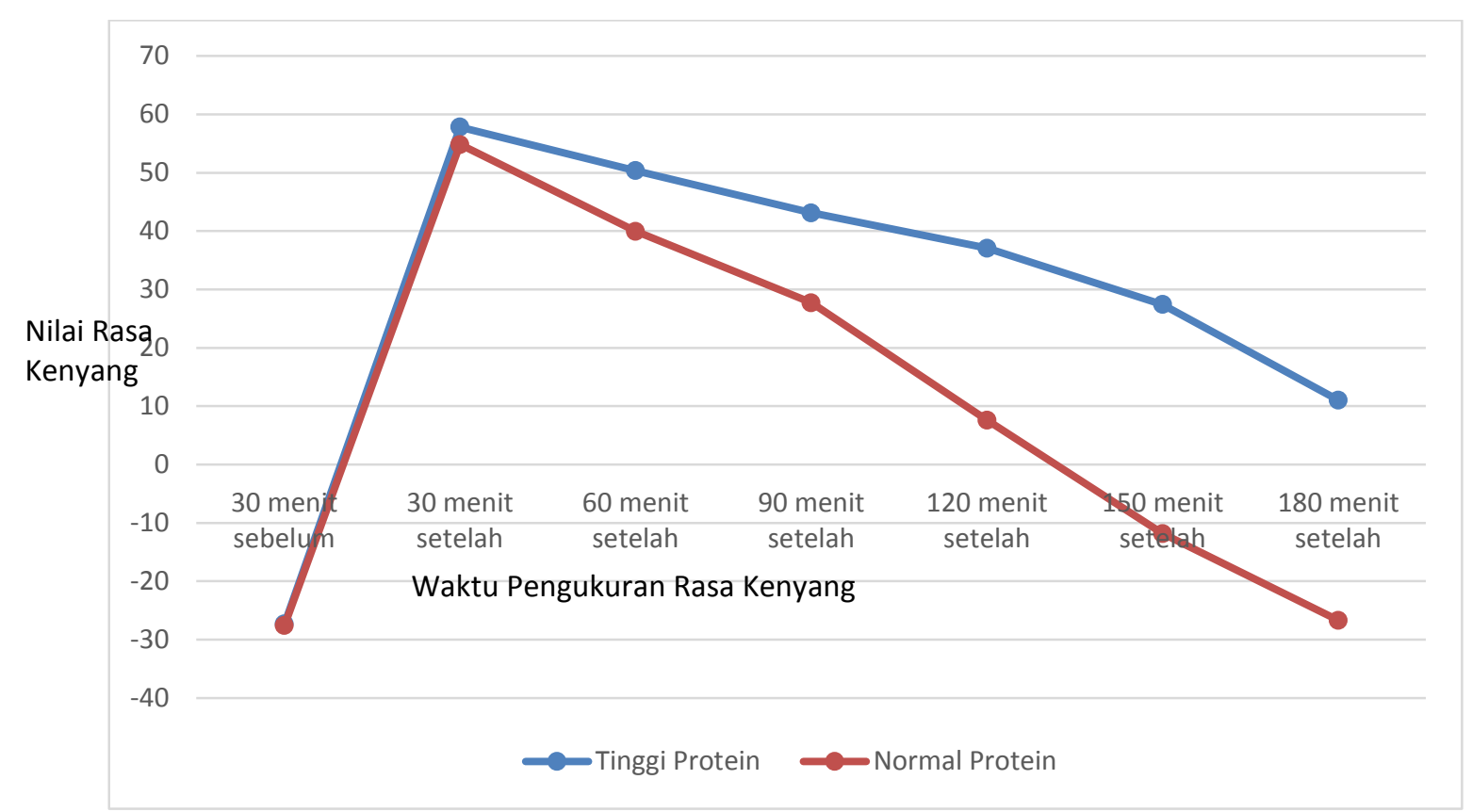

Gambar 1. Perubahan Rasa kenyangselama Intervensi

Gambar 1 menunjukkan perubahan rasa kenyangsubjek selama intervensi yaitu 30 menit sebelum sarapan dan selama 3 jam setelah sarapan. Terlihat bahwa rasa kenyang kedua kelompok hampir sama di 30 menit setelah makan. Perbedaan rasa kenyang mulai terlihat di menit ke60 antara kedua kelompok, sementara kelompok protein normal mengalami penurunan drastis di 120, 150, dan 180 menit setelah makan. Semakin menurun nilai rasa kenyang menunjukkan rasa kenyang subjek yang semakin berkurang, yang artinya subjek semakin lapar.

\section{PEMBAHASAN}

Subjek dalam penelitian ini adalah wanita usia 30 - 60 tahun, bekerja sebagai pegawai negeri sipil (PNS), dan memiliki status gizi obesitas. Kriteria obesitas subjek termasuk dalam obesitas tingkat I dengan Indeks Massa Tubuh (IMT) berkisar antara $25-29,9 \mathrm{~kg} / \mathrm{m}^{2}$. Status gizi berpengaruh terhadap sensitivitas subjek terhadap perubahan rasa kenyang. Penderita obesitas berat (morbid obesity)yang memiliki kadar lemak sangat tinggi akan mengalami kondisi leptin resistance, yaitu suatu keadaan di mana hormon leptin diproduksi sangat tinggi tetapi tidak berpengaruh terhadap penurunan nafsu makan. ${ }^{17,18}$

Sebagian besar subjek memiliki tingkat pendidikan S1 (59,1\%). Aktifitas fisik subjek sebanyak $81,8 \%$ termasuk kategori low activedengan skor PAL antara 1,4 - 1,59, aktifitas seperti ini setara dengan membakar kalori sebanyak 80 - $160 \mathrm{kkal}^{19}$ Aktifitas fisik yang dilakukan subjek saat bekerja sebagian besar adalah duduk untuk mengerjakan pekerjaannya, yaitu mengetik, menulis laporan, dan melakukan pekerjaan kantor.Kadar ureum dan kreatinin darah subjek yang diberi tinggi protein berada dalam batas normal, yaitu $1,8-7 \mathrm{mmol} / \mathrm{L}$ untuk ureum dan $0,5-1,1 \mu \mathrm{mol} /$ Luntuk kreatinin, sehingga fungsi ginjal subjek termasuk sehat dan aman diberi diit tinggi protein.

Hasil recall asupan sarapansebelum intervensi menunjukkan bahwa subjek memiliki kebiasaan sarapan dengan jumlahenergi lebih dari $25 \%$ total kebutuhan. Jenis makanan yang dikonsumsi banyak berasal dari sumber karbohidrat dan lemak seperti nasi dengan bakwan goreng, mendoan, tahu isi, kerupuk, ditambah minum teh manis atau kopi manis. Asupan protein kedua kelompok masih rendah yaitu di bawah $15 \%$ dari total kalori. Hasil uji beda menunjukkan bahwa tidak ada perbedaan kebiasaan sarapan antara kedua kelompok.

Rasa kenyangpada 30 menit sebelum makan menunjukkan bahwa kedua kelompok termasuk dalam tingkat agak lapar $(-18,6)$ dan lumayan lapar $(-38,2)$. Subjek merasa lapar sebab setelah fasting state di malam hari, lambung dalam keadaan kosong dan glukosa darah berada dalam angka minimal. ${ }^{18}$ Rasa lapar menunjukkan kebutuhan akan makanan yang menimbulkan sensasi kuat dan tidak enak di perut. Rasa lapar biasanya muncul $4-6$ jam setelah makan yaitu setelah makanan selesai dicerna oleh lambung dan mulai diabsorpsi.Pusat pengatur rasa lapar terletak di bagian lateral hipotalamus dan menggunakan neuropeptida $\mathrm{Y}$ sebagai transmitter. ${ }^{20}$ Stimulus 
rasa lapardipengaruhi oleh kontraksi dari lambung yang kosong, usus yang kosong, hormon ghrelin, dan faktor eksternal seperti zat gizi dalam darah, ukuran dan komposisi dari makanan, suhu makanan, olahraga, hormonal, penyakit fisik dan mental serta pengobatannya. ${ }^{21}$

Rasa kenyang yang diukur di penelitian ini adalah rasa kenyang setelah makan (inter-meal satiety) yang muncul di akhir waktu makan sehingga dapat mencegah rasa lapar atau keinginan untuk makan dan merupakan faktor penting dalam pengendalian makan yang dapat mempengaruhi asupan total serta pengaturan berat badan. ${ }^{21,22}$ Pemberian sarapan pada kelompok perlakuan diberikan $25 \%$ protein dan $14 \%$ protein pada kelompok kontrol. Hasil ukur pada 30 menit dan 60 menitsetelah makan kedua kelompok menunjukkan bahwa sebagian besar subjek berada dalam tingkat sangat kenyang. Rasa kenyang ini timbul karena lambung masih dalam keadaan penuh setelah terisi makanan.Rasa kenyang mulai menurun menjadi lumayan kenyang pada menit ke-90 karena sebagian makanan sudah mulai dicerna dan masuk ke duodenum. Rasa kenyang menurun secara bertahap di kedua kelompok, dengan penurunan nilai yang lebih besar terjadi pada kelompok kontrol. Pada 150 menit setelah makan, 10 dari 11 orang di kelompok kontrol memiliki nilai minus, dan di akhir pengukuran, seluruh subjek di kelompok kontrol berada dalam kondisi lapar. Sementara nilai minus pada kelompok perlakuan baru muncul pada menit ke180 sebanyak $27,3 \%$.

Hasil uji statistik menunjukkan bahwa perbedaan rasa kenyang yang signifikan antara kelompok perlakuan dan kontrol terjadi di menit ke-120, 150, dan 180 setelah makan. Hal ini menunjukkan bahwakelompok yang diberikan makanan berprotein tinggi mampu menahan rasa laparnya dan tetap merasa cukup kenyang hingga 3 jam setelah makan.

Protein adalah senyawa organik kompleks berbobot molekul tinggi yang merupakan polimer dari monomer-monomer asam alfa amino yang dihubungkan satu sama lain dengan ikatan peptida dan merupakan penyusun terbesar struktur tubuh manusia dan hewan. ${ }^{23}$ Kebutuhan protein harian untuk orang dewasa sehat adalah $0,8-1 \mathrm{~g} / \mathrm{kg} \mathrm{BB}$ atau $10-15 \%$ dari total kalori harian. Dalam kondisi tertentu, kebutuhan protein dapat meningkat hingga 1,2-1,5 g/kgBB atau $18 \%-25 \%$ dari kebutuhan energi total. ${ }^{24}$ Protein memiliki rasa kenyang lebih tinggi dibanding karbohidrat dan lemak karenaprotein memiliki waktu transit yang lebih lama. Molekul protein yang kompleks membuat proses denaturasi lebih sulit. Protein dapat menstimulasi sekresi hormon kolesistokinin dan glucagon like peptide (GLP-1) secara lebih efektif. ${ }^{25}$ Kolesistokinin dan GLP-1 adalah hormon yang disekresikan oleh sel endokrin duodenum untuk meningkatkan rasa kenyang dan memperlambat pengosongan lambung. ${ }^{7,8}$ Selain itu, peningkatan konsentrasi asam amino menstimulasi terjadinya glukoneogenesis sehingga mencegah penurunan kadar glukosa darah. Protein juga memperlambat sekresi ghrelin postpandrial, yaitu hormon yang merangsang nafsu makan. ${ }^{9}$

Penelitian terhadap 9 laki-laki obesitas $\left(\right.$ IMT $\left.\pm 32,7 \mathrm{~kg} / \mathrm{m}^{2}\right)$ di Kansas, Amerika tentang pengaruh makanan tinggi protein terhadap rasa kenyang responden yang diberikan pada waktu sarapan, makan siang, dan makan malam. Masingmasing subjek diberikan 5 jenis pemberian makanan, yaitu makanan dengan protein normal $(0,8 \mathrm{~g} / \mathrm{hari})$, makanan tinggi protein $(1,4 \mathrm{~g} / \mathrm{hari}$ atau $28 \mathrm{~g}$ setiap makan) ketika sarapan, makan siang, makan malam, dan di seluruh waktu makan masing-masing selama 6 hari. Protein yang diberikan $25 \%$ terdiri dari protein hewani seperti telur dan daging babi. Rasa kenyang diukur menggunakan $100 \mathrm{~mm}$ Visual Analogue Scale (VAS) setiap 30 menit sebelum makan dan 30 menit, 60 menit, 90 menit, 120 menit, 150 menit, dan 180 menit setelah makan.Hasil penelitian menyebutkan bahwa makanan tinggi protein yang diberikan ketika sarapan lebih berpengaruh dalam meningkatkan rasa kenyang dibandingkan waktu makan lainnya. ${ }^{11}$

Penelitian lain tentang pengaruh sarapan tinggi protein terhadap rasa kenyang dilakukan di Maastricht, Belanda dengan subjek sebanyak 25 orang dengan BMI $23-30 \mathrm{~kg} / \mathrm{m}^{2}$.Pemberian sarapan dengan protein normal yaitu $10 \%$ dan protein yaitu $25 \%$ dari total energi yang dibutuhkan. Protein yang diberikan bersumber dari kedelai. Rasa kenyang diukur dengan $100 \mathrm{~mm}$ Visual Analogue Scales (VAS)menunjukkan bahwa ada perbedaan rasa kenyang antara kedua kelompok pada 20 menit setelah sarapan. ${ }^{26}$

\section{SIMPULAN}

Ada perbedaan rasa kenyang terhadap pemberian sarapan dengan protein $25 \%$ di menit ke-120, 150, dan 180 setelah makan.

\section{SARAN}

1. Sarapan dengan protein lebih tinggi dengan karbohidrat (nasi) lebih sedikit dapat dijadikan alternatif untuk mengontrol rasa 
lapar dan mencegah ngemil berlebih di pagi hari dalam diit rendah kalori.

2. Penelitian lebih lanjut dengan uji hormon dan uji dampak terhadap penurunan berat badan perlu dilakukan untuk mengetahui pengaruh protein terhadap rasa kenyang.

\section{UCAPAN TERIMA KASIH}

Puji syukur kepada Tuhan Yang Maha Esa dan terima kasih kepada Ibu Tatik Mulyati, DCN., M.Kes. yang telah membimbing dalam kegiatan penelitian ini dari awal hingga akhir serta kepada reviewer yang telah membimbing penelitian ini. Selain itu ucapan terima kasih disampaikan kepada orang tua dan teman-teman yang telah memberikan motivasi dan dukungan bagi penelitian ini.

\section{DAFTAR PUSTAKA}

1. World Health Organization. Obesity and Overweight. Switzerland: World Health Organization; 2012.

2. Badan Penelitian dan Pengembangan Kesehatan. Riset Kesehatan Dasar 2013. Jakarta: Kementerian Kesehatan Republik Indonesia; 2013.

3. Badan Penelitian dan Pengembangan Kesehatan. Riset Kesehatan Dasar 2010. Jakarta: Kementerian Kesehatan Republik Indonesia; 2010.

4. Centers for Disease Control and Prevention. OverweightandObesity.USA:

DepartmentofHealthandHuman Services; 2006. Available

from:www.cdc.gov/ncchphp/dnpa/obesity/

5. Cummings DE, SchwartzMW. Genetics and Pathophysiology of Human Obesity. Annu Rev Med. 2003;54:453-71.

6. Eisenstein J, Roberts SB, Dallal G, and Saltzman E.High-protein weight-loss diets: are they safe and do they work? A review of the experimental and epidemiologic data. NutrRev.2002;60(7):189-200.

7. Potier M, Darcel N, and Tome D.Protein, amino acids and the control of food intake. Clin N Metab Care. 2009;12(1):54-58.

8. Yamada T. Textbook of Gastroenterology Vol 1. 5thed. London: Wiley-Black Well; 2011. p. 320323.

9. WrenAM, Seal LJ, Cohen MA, Brynes AE, Frost GS, Murphy KG, et al. Ghrelin Enhances Appetiteand Increases Food Intake in Humans. J Clin Endocrinol Metab. 2001;86:5992.

10. Blom WAM, Lluch A, Stafleu A, Vinoy S, Holst JJ, Schaafsma G, et al. Effects of Gastric Emptying on The Postprandial Ghrelin Response. Am J Physiol Endocrinol Metab. 2006;290: E389 $-\mathrm{E} 395$.

11. Leidy HJ, Bossingham MJ, Mattes RD, and Campbell W. Increased Dietary Protein Consumed at Breakfast Leadstoan Initial and
Sustained Feelingof Fullness During Energi Restriction Compared toOther Meal Times. Br J Nutr. 2009;101:798-803.

12. de Castro JM. The Time of Day and the Proportions of Macronutrients Eaten are Related to Total Daily Food Intake. $\mathrm{Br} \quad \mathrm{J}$ Nutr.2007;98(5):1077-83.

13. Purslow LR, Sandhul MS, Forouhi N, Young EH, Luben RN, Welch AA, et al. Energi Intake at Breakfast and Weight Change: Prospective Study of 6,764 Middle-aged Men and Women. Am J Epidemiol 2008;167:188-192.

14. Schusdziarra V, Hausmann M, Wittke C, Mittermeier J, Kellner M, Naumann A, et al.Impact of Breakfast on Daily Energy Intake An Analysis of Absolute Versus Relative Breakfast Calories. Nutrition Journal 2011;10:5.

15. U.S Department of Health and Human Services. National Institute of Health Obesity Education Inisiative : The Practical Guide: Identification, Evaluation, and Treatment of Overweight and Obesity in Adults. Washington DC; 2000. p. 27.

16. Cardello A, Schutz HG, Lesher LL, and Merrill E. The Creation and Testing of a Scale to Measure the Subjective Experiences of Hunger and Satiety. JAppetite 2005;44:1-13.

17. Sizer F, Whitney E. Nutrition: Concepts and Controversies. $11^{\text {th }}$ ed. USA: Thomson Wadsworth; 2007. p. 332.

18. Leidy HJ, Carnell NS, Mattes RD, and Campbell WW. Higher Protein Intake Preserves Lean Mass and Satiety with Weight Loss in Pre-obese and Obese Women. Obesity.2007;15(2):421-429.

19. Mahan LK, Escott-Stump S.Krause's Food and Nutrition Theraphy. $12^{\text {th }}$ ed. USA: Elsevier; 2010. p. 35 .

20. Bender DA. Nutrition and Metabolism $4^{\text {th }}$ Ed. USA: CRC Press; 2010. p. 5.

21. Sizer F, Whitney E.Nutrition: Concepts and Controversies $11^{\text {th }}$ Edition. USA: Thomson Wadsworth; 2007. p. 323-331.

22. Karalus MB.The Creation and Testing of a Scale to Measure the Subjective Experiences of Hunger and Satiety. USA: University of Minnesota; 2011.

23. F.G. Winarno. Kimia Pangan dan Gizi. Jakarta: PT Gramedia Pustaka Utama; 2004.

24. World Health Organization. Protein and Amino Acid Requirement in Human Nutrition : Report of a Join WHO/FAO/UNU. Geneva: World Health Organization; 2002.

25. Astrup A. The Satiating Power of Protein-A Key yo Obesity Prevention?. Am J Clin Nutr 2005;82:1-2.

26. Veldhorst MAB, Nieuwenhuizen AG, Hochstenbach-Waelwn A, Westerterp KR, Engelen M, Brummer RM, et al. Effect of High and Normal Soyprotein Breakfasts on Satiety and Subsequent Energy Intake, Including Amino Acid and Satiety Hormone Response. Eur J Nutr. 2009;48:92-100 